Section Editor

Mitchell S.V. Elkind, MD, MS

\section{Eytan Raz, MD}

Girish Fatterpekar, MD Adam J. Davis, MD

Paul P. Huang, MD John P. Loh, MD

Correspondence \& reprint requests to Dr. Raz: eytan.raz@gmail.com

Mystery Case:

\title{
Idiopathic bilateral stenosis of the foramina of Monro
}

\section{Figure $1 \quad$ MRI of the brain}



Axial T2-weighted images demonstrate dilated lateral ventricles. The third ventricle is slit-like. There is downwards transtentorial herniation of the midbrain.

A 42-year-old man presented with chronic, continuous, bifrontal pressure headaches, slightly worse in the morning, forgetfulness, and confusion. There was no history of prior CNS hemorrhage or infection. The neurologic examination was unremarkable. No papilledema was present. Neuroimaging demon- strated symmetric enlargement of the lateral ventricles, a slit-like third ventricle, and downwards transtentorial herniation (figure 1). No mass lesion or abnormal enhancement was seen. A diagnosis of idiopathic bilateral stenosis of the foramina of Monro was considered. The patient underwent endoscopic

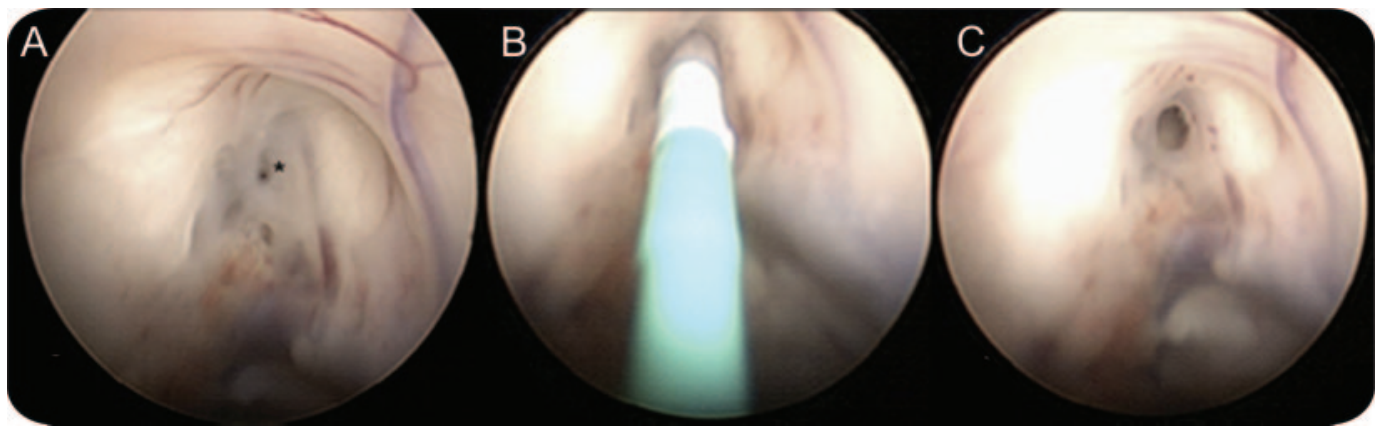

(A) Intraoperative endoscopic photograph shows a thin, translucent membrane covering the left foramen of Monro (asterisk). There is no evidence of tumor. (B) A Fogarty catheter was inserted through this web and inflated. (C) After removal of the catheter, a patent foramen of Monro is seen. A septostomy was subsequently performed to allow CSF flow from the right lateral ventricle into the now patent left foramen of Monro.

From the Department of Radiology, Division of Neuroradiology (E.R., G.F., A.J.D., J.P.L.), and Department of Neurosurgery (P.P.H.), NYU Langone Medical Center, New York, NY.

The authors report no disclosures relevant to the manuscript. Go to Neurology.org for full disclosures. 
foraminoplasty of the left foramen of Monro and septoplasty (figure 2). Follow-up demonstrated resolution of the hydrocephalus and regression of symptoms. Nine cases of idiopathic bilateral stenosis of the foramina of Monro have been published. ${ }^{1}$ Bilateral lateral ventricular hydrocephalus and a slit-like third ventricle in the absence of focal mass lesion or abnormal enhancement at the foramina of Monro should raise a red flag for this uncommon treatable entity. ${ }^{2}$

\section{AUTHOR CONTRIBUTIONS}

Dr. Raz: manuscript drafting and literature research. Dr. Fatterpekar: revising the manuscript for intellectual content. Dr. Davis: revising the manuscript for intellectual content and literature research. Dr. Huang: manuscript drafting and revising the manuscript for intellectual content. Dr. Loh: revising the manuscript for intellectual content.

\section{REFERENCES}

1. Kalhorn SP, Strom RG, Harter DH. Idiopathic bilateral stenosis of the foramina of Monro treated using endoscopic foraminoplasty and septostomy. Neurosurg Focus 2011;30:E5.

2. Martínez-Berganza MT, Bergua BS, del Río Pérez C, Ballarín SM. Biventricular hydrocephalus due to idiopathic occlusion of foramina of Monro. Neurologist 2011;17: $154-156$.

\section{MYSTERY CASE RESPONSES}

The Mystery Case series was initiated by the Neurology ${ }^{\circledR}$ Resident \& Fellow Section to develop the clinical reasoning skills of the trainees. Residency programs, medical student preceptors, and individuals were invited to use this Mystery Case as an education tool. Responses were solicited through a group e-mail sent to the AAN Consortium of Neurology Residents and Fellows and through social media.

All the answers that we received came from individual residents rather than groups and they were all well-reasoned and thoughtful. The majority of them came through social media. Respondents all correctly identified the symmetric enlargement of the lateral ventricles associated with a small third ventricle. Putative diagnoses included noncommunicating hydrocephalus (13\%), normal pressure hydrocephalus (68\%), chronic meningitis (8\%), and aqueductal stenosis (4\%).

This Mystery Case illustrates idiopathic bilateral stenosis of the foramina of Monro, an uncommon cause of noncommunicating hydrocephalus.

Dragos A. Nita, MD, PhD

The Hospital for Sick Children, University of Toronto, Toronto, Canada 


\section{Neurology}

\section{Mystery Case: Idiopathic bilateral stenosis of the foramina of Monro \\ Eytan Raz, Girish Fatterpekar, Adam J. Davis, et al. \\ Neurology 2012;79; e166-e167 \\ DOI 10.1212/WNL.0b013e318271f792}

This information is current as of October 29, 2012

\section{Updated Information \& Services}

References

Subspecialty Collections

Permissions \& Licensing

Reprints including high resolution figures, can be found at: http://n.neurology.org/content/79/18/e166.full

This article cites 2 articles, 0 of which you can access for free at: http://n.neurology.org/content/79/18/e166.full\#ref-list-1

This article, along with others on similar topics, appears in the following collection(s):

All Imaging

http://n.neurology.org/cgi/collection/all_imaging

CT

http://n.neurology.org/cgi/collection/ct

Hydrocephalus

http://n.neurology.org/cgi/collection/hydrocephalus

MRI

http://n.neurology.org/cgi/collection/mri

Post-infectious

http://n.neurology.org/cgi/collection/postinfectious_

Information about reproducing this article in parts (figures,tables) or in its entirety can be found online at:

http://www.neurology.org/about/about_the_journal\#permissions

Information about ordering reprints can be found online:

http://n.neurology.org/subscribers/advertise

Neurology ${ }^{\circledR}$ is the official journal of the American Academy of Neurology. Published continuously since 1951, it is now a weekly with 48 issues per year. Copyright Copyright (? 2012 by AAN Enterprises, Inc.. All rights reserved. Print ISSN: 0028-3878. Online ISSN: 1526-632X.



